ment commenced some years ago, which has given interesting results. The removal of mussels from overcrowded beds and the laying down of new grounds and the restocking of old ones has proved eminently successful, and the increased rate of growth of transplanted individuals is very marked.

From the report on the sea-fish hatching at Piel we learn that more than a million plaice larvæ and nearly twelve million flounder larvæ were liberated during the breeding season, and a similar report upon the sea-fish hatching at Port Erin shows that five million plaice larvæ were liberated off the Isle of Man, but we look in vain for any word which will show us that the liberation of these fry during several years has produced any effect upon the fisheries of the district.

An interesting paper upon trawling observations, by $\mathrm{Mr}$. James Johnstone, contains a section upon the food of plaice, dabs, and other fishes, and we gather that the results so far obtained tend to show that the plaice and the dab are not competitors for food, although living upon the same ground; that whereas the former feed chiefly upon molluscs, the latter prefer Ophiurids and Crustacea, although they are less particular as to the nature of their food than are the plaice. Mr. Todd's observations as to the food of these species in the North Sea seem to bear out the omnivorous tendency of the dab, but they also seem to show that the chief food of both species in that region consists of molluses.

Mr. Johnstone also contributes a paper on the marked fish experiments, in which he sets out the migrations of the plaice in the district, as shown by the re-capture of marked specimens. He finds that the fish tend to move along the shore lines during the winter months, and to migrate off-shore during the summer months, which facts appear to agree with the results so far determined as to the migrations of this species in the North Sea.

$\mathrm{Mr}$. Andrew Scott's report on the tow-nettings for the year contains a large amount of material, but the author has not drawn conclusions therefrom, so that the paper is somewhat heavy reading.

Prof. Herdman's paper upon the oligodynamic action of copper, dealing with the possibilities of purifying infected shell-fish by immersion in distilled water which has been in contact with copper-foil, is extremely interesting, but is in the nature of a preliminary statement, as he is about to investigate the whole question in conjunction with Prof. B. Moore

The volume is illustrated, including a useful series of plates of copepods, trematodes, \&c., in connection with Mr. Andrew Scott's "Faunistic Notes."

Frank Balfour Browne.

\section{PHYSIOLOGICAL EFFECTS OF MENTAL} ACTIONS.

THE most recent number of the Beiträge zur Psychologie und Philosophie (Band i., Heft 4) contains two articles, one by the editor, Prof. Martius, on the theory of the influence exerted on pulse and respiration by mental stimuli, while the other, by Mr. C. Minnemann, discusses pulse and respiration as studied in the subjects of genuine, first-hand emotion. Prof. Martius starts with pointing out the. contradictory opinions held by other investigators regarding the effect of attention, of joyful or painful emotions on pulse and respiration. This diversity he regards as partly due to the neglect of several precautions, and he proceeds to study, amongst other points, those fluctuations of the pulse which are in direct correspondence witk respiration periods. He then examines the plethysmographic method, and comes to the conclusion that variations of volume registered by it are partly due to movements of the limb under investigation, and that the method cannot be used at present to secure any definite results regarding the circulation of the blood.

Elaborate details and analyses are next given of his experiments on five human subjects; they are classed thus:-(I) effects on the pulse of artificial alterations in respiration (e.g. deepening, acceleration, retardation of breathing); (2) effects of bodily activity on pulse : and respiration; (3) effects of mental activity; (4) effects of bodily pain ; (5) effects of taste and smell (whether pleasant or unpleasant; (6) effects of moods (of joy and depression) artificially induced, e.g. by hearing witty stories, recalling the contents of certain poems, or the like.

With regard to many points Prof. Martius thinks that definite conclusions are at present impossible; all that he regards as established is the presence of a series of types of general emotional or " affective" states, and especially the distinction of the two types of activity and rest. But the methods described are insufficient to characterise definitely for us special emotions like those of fear or sympathy. It seems established, too, that joy and sorrow do not possess definite complexes of symptoms by which they can be separated from one another, and further, bodily and mental activity produce the same appearances. Hence while the will and the intellect are not to be regarded as one, they cannot be separated, and we can never analyse the products of intellect merely into sensations and feelings. The other article follows the same lines and reaches a similarly safe conclusion, that we can read out of the experiment curves nothing but the most general characteristics of emotional states, viz. excitement or repression.

\section{DISCOVERY OF SEVEN THOUSAND ROMAN COINS.}

A COARSE earthenware jar containing upwards of seven thousand "third brass" Roman coins was recently unearthed by the ploughshare on the farm of Mrs. Wheatley, Stanley, near Wakefield. In very early times the bed of the river Calder, which has a remarkable sweep at this point, was deepened by the ancient Britons or Romans, and an embankment made with the sand; in this the jar, with its contents, was deposited I 500 years ago.

The coins all belong to the Constantinian group; to Constantine the Great, to his mother Helena, his stepmother Theodora, his four sons, Crispus, Constantine, Constantius, and Constans, Licinius his brother-in-law, with his wife Constantina and their son Licinius, and to Delmatius. The reverses are chiefly of the "Gloria Exercitus" type.

One-half, of nearly five thcusand coins, which I have carefully examined is, in about equal quantities, of the "Urbs Roma" type, with wolf and twins on the reverse, and "Constantinopolis," with a Victory on the reverse with spear and shield, standing on the prow of a vessel; these latter were struck to commemorate the founding of Constantinople A.D. 330. 'T here are twelve represented of the twenty-four mints of issue known to us, among which are Carthage, Alexandria, Antioch Rome; but most are from Treves in Germany, the residence of the governor of the west, Lyons, and Constantina, now Arles in France.

Very few of them, if any, have ever been in circulation. They are most likely a portion of a military chest concealed during a threatened raid or invasion. It is remarkable that ten or twelve years ago a find of seventeen thousand was made in the Forest of Dean, covering the same period, of exactly the same types, with a similar redundancy of certain coins and a scarcity of others. A series of the Stanley coins has been presented to the museum of the Leeds Philosophical and Literary Society, and are now on exhibition. Aguila DodGson

\section{UNIVERSITY AND EDUCATIONAL INTE LLIGENCE.}

OxFord.-The date of the fellowship examination in chemistry at Merton College has been altered from September 25 to September I8. Candidates are asked to send their names to the Warden on or before September I, and to call on him on September I7, by which date they should submit to him any dissertations or papers, or evidence of research they have done.

During the vacancy of the Linacre chair of comparative anatomy, Mr. Edwin S. Goodrich, fellow of Merton College, has been appointed to act as deputy-professor.

New College has resolved to raise the college contribution to the stipend of the Wykeham professor of physics to $65 \mathrm{ol}$. a year, thereby increasing the total income of the professorship to $800 l$. a year.

NO. 1905, VOL. 74$]$ 